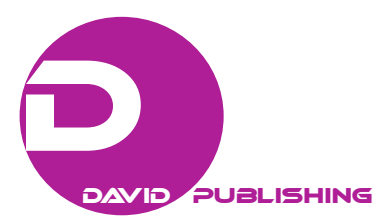

\title{
State Policy on the Environment in Vietnamese
} \section{Handicraft Villages}

\author{
Nguyen Thi Thu Huong \\ Hanoi Open University, Hanoi, Vietnam
}

\begin{abstract}
Handicraft villages play an important role in promoting social and economic development in rural areas as well as Vietnam's economy. Nowadays, Vietnam's handicrafts have a foothold in the world market, and are exported over 163 countries and territories (Tuan, 2010). However, the production activities of the handicraft village have a lot of shortcomings, especially the problem of environmental pollution (Chi, 2010). Therefore, government policy plays a very important role to minimize environmental pollution villages, contributing to improving environmental quality and public health. This paper focuses on: 1). Current status of state policy environment in handicraft villages shows the achievements and limitations of the policy, from which reviews state policy in environments in handicraft villages (through fieldwork in the handicraft villages); and 2). Solution to improve state policy on environmental protection in handicraft villages in Vietnam.
\end{abstract}

Keywords: craft village, state policy, environmental policy

\section{Introduction}

Craft village handicrafts play an important role in the economic development of the local society and Vietnamese economy. Now, there are about 3,000 villages, including the village handicrafts accounted for nearly $40 \%$, attract about 13 million workers and 1.4 million households engaged in manufacturing. Vietnam's rural population accounts for over 70\% of the villages (Huong, 2010). That has seen really important role in attracting more jobs, maintaining stable lives, and reating higher income levels from two to four times agricultural laborers. More particularly, arts and crafts are group created huge value-added, effective high socio-economic. Although the crafts villages have a positive contribution to exports, the restructuring of the rural economy, as well as many social and economic benefits others, however, the crafts village today still have many difficulties, not to promote their potential. To develop handicraft villages in Vietnam in terms of international economic integration, businesses and individual households can not be effectively implemented for production and business activities in villages required high community. Moreover, the village is vulnerable subjects, and should be protected in this integration process. Therefore, government policies (The Ministry of Agriculture and Rural Development, 2007) have an important role for the overall development of villages and handicraft villages in particular and the improvement of state policy on the development of handicraft villages of Vietnam is essential and practical significance. Moreover, the production activities of the handicraft village have a lot of shortcomings, especially the problem of environmental pollution. Therefore, government policy

Nguyen Thi Thu Huong, Ph.D., Faculty of Economics and Business Administration, Hanoi Open University, Hanoi, Vietnam.

Correspondence concerning this article should be addressed to Nguyen Thi Thu Huong, Faculty of Economics and Business Administration, Hanoi Open University, Hanoi, Vietnam. 
plays a very important role to minimize environmental pollution villages, contributing to improving environmental quality and public health.

Overall objective of this article is to improve public policy on environment for developing Vietnamese handicrafts village. Specific objectives: (1) Assessment of the status of state policy on environment for the development of handicraft villages in Vietnam. Thereby, it indicates the achievements, limitations, and their causes; and (2) Recommend perspective, solutions to improve environmental policies to develop handicraft village Vietnam.

\section{Research Methods}

The content on research focused mainly on evaluating and improving the content of the policy of the state (topic does not studied in depth the policy process), and also paid attention to the conditions for a system of policies promoting the beneficial effects for the development of handicraft villages in Vietnam. Many policies affect the development of craft villages such as: policy on planned villages, products in villages; policy on investment and credit; policy on science and technology; policy on human resources; and policy on trade, in which environmental policies are studied in detail.

Space and object surveys: surveying handicrafts villages in the provinces/cities mainly in the North. Surveying some sectors/products such as handicrafts typical: (1) ceramic art; (2) art wood; (3) lacquer; (4) rattan; (5) silk; (6) embroidery; (7) carved stone; and (8) metal casting. The survey (for production facilities) was conducted for businesses operating in the village handicrafts and was selected by random form. The number of surveys is full of information and used in the study was $106(n=106)$.

Study period: focusing on the state policy on the development of handicraft villages in Vietnam in the period from 2000 to present and forecasts to 2020.

\section{Research Methodology}

- Data collection method: The topic used a combination of methods to collect secondary data and primary research methods of quantitative and qualitative research methods to get the information.

- Processing methods, data analysis: This topic has used statistical techniques, econometrics, and SPSS software applications to process data collected.

\section{Research Results}

Policy on investment in infrastructure and processing environment are specified through documents such as: The Decree No. 80/2006/ND dated 9/8/2006 of the government expressed regulations and guidelines for implementation of some articles of the Law on Environmental Protection. Decision No. 277/2006/QD-TTg dated 11/12/2006 of the Prime Minister approved the "National target program on clean water and rural sanitation in the 2006-2010 period”. Decision No. 13/2009/QD-TTg dated 21/01/2009 of the Prime Minister expressed the use of investment credit capital for development investment to continue to implement the program on solidification of canals, roads development rural, infrastructure for aquaculture, and infrastructure in rural villages in the period of 2009-2015. Joint Circular No. 31/2009/BCT-BTNMT TTLT of Industry and Trade Ministry and the Ministry of Natural Resources and Environment guide the coordination between the Department of Trade and Department of Natural Resources and Environment to implement state management of environmental protection in the areas of trade. Decision 1216/QD-TTg dated 05/9/2012 approved the “Strategic national environmental protection until 2020 and vision to 2030” (The Government, 2011)... 


\section{Based on Recognizable Content, the Text of the Policy}

Some basic content about environment handicraft villages is focused on studies and surveys as shown in Table 1:

Table 1

Review the Knowledge Content of Policy on Environment

\begin{tabular}{lrc}
\hline & \multicolumn{2}{c}{$\begin{array}{c}\text { Percentage of firms interested } \\
\text { or know the contents (\%) }\end{array}$} \\
\cline { 2 - 3 } & Yes & No \\
\hline 1. Financial support and technology transfer waste treatment, solve environmental pollution villages & 70.75 & 29.25 \\
2. Support application of new technologies, new materials, pollution control technology... & 65.09 & 34.91 \\
3. Support investment, infrastructure construction and environmental remediation villages & 72.64 & 27.36 \\
4. Funding support for science and technology in order to reduce environmental pollution & 70.19 & 29.81 \\
5. Technological innovation and application of techniques to minimize environmental pollution & 74.91 & 25.09 \\
6. Communication and education, raise awareness about the environment in the village & 83.02 & 16.98 \\
\hline
\end{tabular}

Source: Result of survey.

In general, enterprises have known and understood the contents related to environmental policy for handicrafts villages but it is not high (proportion of about $72 \%$ ).

\section{Based on the Criteria for Evaluating Policies}

Based on the criteria for evaluating policies, environmental policies are assessed as follows (Table 2):

Table 2

Evaluating Policy on Environment

\begin{tabular}{lllllll}
\hline \multicolumn{7}{c}{ Statistics } \\
\hline & $\begin{array}{l}\text { Transparency of } \\
\text { policy }\end{array}$ & $\begin{array}{l}\text { Relevant of } \\
\text { policy }\end{array}$ & $\begin{array}{l}\text { Consistency of } \\
\text { policy }\end{array}$ & $\begin{array}{l}\text { Stability of } \\
\text { policy }\end{array}$ & $\begin{array}{l}\text { Effectiveness of } \\
\text { policy }\end{array}$ & $\begin{array}{l}\text { Efficiency of } \\
\text { policy }\end{array}$ \\
\hline$N$ & 106 & 106 & 106 & 106 & 106 & 106 \\
Mean & 3.78 & 3.81 & 3.22 & 2.83 & 2.82 & 2.85 \\
Std. Deviation & 0.926 & 0.782 & 0.926 & 0.878 & 0.924 & 0.766 \\
Variance & 0.857 & 0.612 & 0.857 & 0.771 & 0.853 & 0.587 \\
\hline
\end{tabular}

Source: Result of survey.

Transparency of policies: enterprises agree the transparency of government policy on the environment to develop handicrafts villages in nowaday (rate "agree” accounted for $44.3 \%$ and "totally agree” accounted for 21.7\%). The average of evaluation point is 3.78. That suggests this is the achievement of public policy that should be promoted in the coming period.

Relevance of the policy: the compatibility of policy methods can be judged by the extent to which policy can adapt to the change of market, technology, knowledge, social, political conditions, and environment. State policy of village environment is considered appropriate in the current period (average evaluation score 3.81).

Consistency of the policy: percentage of enterprises evaluates level of "neutral” and "agree” on the policy consistency of high percentage (35.8\%). The assessment "disagree" on the consistency of policies is $19.8 \%$. This is a relatively high proportion of "disagree" compared with other criteria. Average rating of 3.22 points shows that enterprises evaluate the state policy on environment in current is handicrafts village, which is consistency (over 70\%). So, this is the criterion that the state should pay attention, complete more in the future to enhance the role of the policy. 


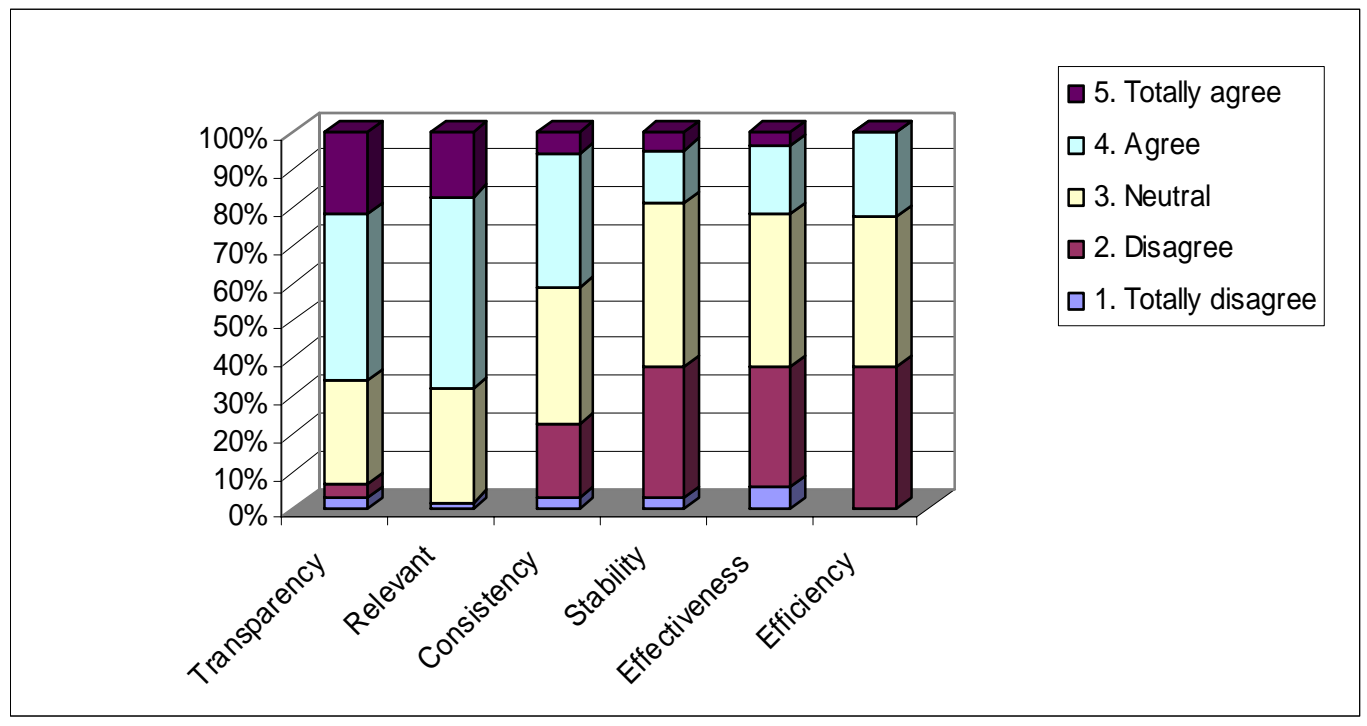

Figure 1. Chart evaluating policy on environment.

Other criteria assessed at below average as:

- Stability of policies: the proportion of enterprises evaluating the stability of the state policy on the environment in the village handicrafts is not high (average score 2.83). This shows that instability is a limitation of current government policies.

- Effectiveness of the policy: enterprises evaluate the effectiveness of government policies on the environment in craft villages is 2.82 .

- Efficiency of the policy: the average score is 2.85, the level of evaluation criteria is "disagree" accounted high with 37.7\%; "neutral” accounted for 39.6\%.

\section{Based on the Satisfication of Policy}

By evaluating the recognition content of policy and the participation of enterprises on policy, the general level of satisfaction for environmental policy is shown in detail in Table 3:

Table 3

\section{Evaluating the Satisfication of Policy on Environment}

\begin{tabular}{llllc}
\hline Contents & Frequency & Percent & & Statistics \\
\hline 1. Completely dissatisfied & 1 & 0.9 & Mean & 2.7 \\
2. Dissatisfied & 44 & 41.5 & Median & 3 \\
3. Neutral & 46 & 43.4 & Mode & 3 \\
4. Satisfied & 15 & 14.2 & Std. Deviation & 0.716 \\
5. Completely satisfied & 0 & 0 & Variance & 0.513 \\
Tong & 106 & 100 & & \\
\hline
\end{tabular}

Source: Result of survey.

The general assessment of the level of satisfaction of environmental policy in Table 3 shows that the level of satisfaction of this policy is assessed at low level, with an average score of 2.7 (Mean 2.7). The percentage of “completely dissatisfied”, "dissatisfied”, or "normal” policy occupies quite high, about 85\%; the number of enterprises that evaluating "satisfied" is low rate (approximately 14.2\%). This suggests that policies on environment are not appreciated. 


\section{Discussion and Conclusion}

General assessments of environmental policy on the development of Vietnamese handicrafts villages are as followings:

- Positive, progressive: First, the formulation and promulgation and enforcement of the legal documents, policies have created a legal framework for village activities and development. Second, the policy department in different areas has many practical solutions for the development of villages in protecting environment such as investment, credit, science and technology, human resources... Third, in the survey results, a number of respondent appreciated through each different criterion of policies.

- The limitations and weaknesses: First, the state's policy for villages is missing or incomplete. Second, the documents specified, the relevant procedural guidelines have not materialized forms; policy documents lack convincing, there are clearances. Third, a number of village development policies in different fields are problematic gaps. Fourth, some criteria have many limitations, not highly evaluated through surveys.

- The cause of the limitations and weaknesses includes policy itself and the conditions to ensure. The cause of the policy itself such as: support for scientific research and technological application of new technologies for the production of handicrafts villages are limited; the management, direction, and administration of environmental protection work in the village are inadequate; the system of legal documents on environmental protection for villages is lacking, inconsistent, and overlapping. Writing system, although is relatively slow, but progress is issued. The cause of the conditions includes: the staff build and implement organizational policies, the apparatus constructed and organized policy implementation, the resources for the formulation and implementation of policies, sanctions and measures to control the formulation, and implementation of policies.

So, the solutions to improve the policy on environment for the development of Vietnamese handicraft villages should focus on the following:

- Investment in infrastructure: Support development of the transport system in the village; support the development of communication systems; and support construction of water supply and drainage to protect environment in villages.

- Building, perfecting mechanisms, and policies to improve the efficiency of the state management of the environment: Needing a specialized department is responsible for inspecting the implementation of environmental protection, there are provisions sanctioned for businesses and households that produce violations of environmental protection laws.

- Organizing the long-term training focus for managers, technicians' environmental protection from the commune to the central level. Agencies and departments related to environmental pollution treatment villages coordinated implementation.

- Selecting technological and environmental equipment for the village to increase investment in science and technology development to environmental protection. Technological and environmental processing equipment advanced in the world should be models of environmental remediation for the villages that are located near populated areas from the state budget. On the application of technology, the ability to operate the equipment and funds to buy the materials need match the workers' earnings. For production facilities scattered, encouraging the adoption of technologies locally treated waste gas and waste water; applying the technology is easy to use and operate accordance with the level of knowledge of the people, the priority utilization and reuse of waste; and application of new materials in production. 
- The other solution to ensure conditions to improve state policy on the development of Vietnamese handicrafts villages such as: (1) Solution of the policy makers and policy implementation: building a team of consultants, professional strategic thinking in the sector, the sector of economic life-society, from middle local level, agencies, and units; working arrangements in accordance with the qualifications, competence, and quality of staff; attracting intellectual resources in the formulation and implementation of policies; retraining and restructuring of staff policy towards improving quality, ensuring consistency, inheritance, and development; expanding co-operation and exchange of experience with a team of consultants strategic countries in the region and internationally; (2) Solutions to organize system construction and implementation of policies: creating active collaboration of the authorities from central to local levels; there should be coordination between the units and the organization of the state; needing the active participation of members in policy formulation; (3) Solutions to invest resources to construction and implement policy: aside adequate funds for the construction, implementation, and policy evaluation; increasing resources for the formulation and implementation of policies such as the cost of building infrastructure for the implementation of the policy; procurement of equipment, supplies, technical equipment, and other material costs; and (4) The sanctions and other measures.

In summary, on the basis of the situation of handicraft village in Vietnam, the article has selected the criteria for evaluating development policies handicrafts villages including: transparency of policy, relevant of policy, stability/sustainability of policy, consistency of policy, effectiveness of policy, and efficiency of policy. Also, the topic also evaluates envionmental policy based policy evaluation criteria and indicates achievements, limitations, and causes. Based on the status of the policy, the topic proposes solutions in order to improve envionmental policy in the development of Vietnamese handicraft villages, while providing the necessary conditions to improve the policy system.

\section{References}

Chi, D. K. (2010). Handbook apply solutions to improve the environment for craft villages. Ha Noi: Science \& Technology publisher.

Huong, N. T. T. (2010). Managing the environmental state in the handicraft craft villages in Vietnam. Journal of Development Economics, 168(II), 70.

The Government. (2011). Report on the implementation of policies and environmental legislation in the economic area, craft villages (Implementation of Resolution No. 1014/NQ/UBTVQH 12), Hanoi.

The Ministry of Agriculture and Rural Development. (2007). Some of policies on rural industries development. Hanoi: Agriculture Publisher.

Tuan, Vu. Q. (2010). Villages_Vocational city of Thang Long_Hanoi on the way of development. Published by Hanoi, Hanoi. 